\title{
ISPITIVANJE ZVUČNE IZOLACIJE U NOVOIZGRAĐENOJ ZGRADI ${ }^{4}$
}

\section{SAŽETAK}

Provedeno je terensko mjerenje buke i zvučne izolacije u radnom i životnom okolišu na stambeno-poslovnoj novoizgrađenoj zgradi u Pazinu u ulici M. Belušića prema Zakonu o zaštiti od buke NN br. 30/09, Pravilniku o zaštiti radnika od izloženosti buci na radu NN br. 46/08, Pravilniku o najvišim dopuštenim razinama buke u sredini u kojoj ljudi rade i borave NN br. 145/04. Mjerenje buke izvršeno je zvukomjerom Brüel \& Kjaer 2250 te se zvuk, odnosno bijeli šum, reproducirao pomoću uređaja toptalica (5 čekića na bregastoj osovini). Zvuk se mjerio u prijamnoj i u predajnoj sobi kako bi se odredio indeks zvučne izolacije Rw. Nakon analize i obrade podataka dobiveni rezultati uspoređeni su s važećim propisima. U radu su objašnjeni osnovni pojmovi vezani uz opis, mjerenja i uturdivanja akustičkih parametara te posljedice dugotrajnog utjecaja izlaganja prekomjernim razinama buke kod čovjeka. Pri tome dane su i smjernice te preporuke za zaštitu od buke.

Ključne riječi: buka, zvučna izolacija, osobna zaštitna oprema, sigurnost.

\section{UVOD}

$U$ istraživanju će se prikazati objektivno terensko mjerenje zvučne izolacije u novoizgrađenoj stambeno-poslovnoj građevini, ulica M. Belušića na lokaciji k. č. 2259/3 k. o. Pazin. Ispitat će se utjecaj zračnih i udarnih zvučnih valova na kvalitetu zvučne izolacije. Dobiveni podaci usporedit će se $s$ propisanim podacima prema Pravilniku o dopuštenim razinama buke u sredini u kojoj ljudi rade i borave (NN br. 145/04). U slučaju da izmjereni podaci prelaze dozvoljene granične vrijednosti, predložit ćemo mjere poboljšanja kojima se buka može smanjiti na dopuštenu razinu. Buka predstavlja svaki neželjeni zvuk, a mjeri razinu zvučnog tlaka $\left(L_{p}\right)$ koja predstavlja odnos izmjerenog tlaka $(p)$ i tlaka koji predstavlja prag čujnosti kod ljudi $\left(p_{0}=20 \mu \mathrm{Pa}\right),(1)$.

$$
L_{p}=10 \cdot \log \frac{p^{2}}{p_{0}^{2}}=20 \cdot \log \frac{p}{p_{0}} \mathrm{~dB}
$$

Zvuk se u zraku širi zbog poremećaja koji može biti pomak čestica, gustoće, tlaka ili temperature malog dijela medija (Sever, 2007:41). Valovi se kroz krute, tekuće i plinovite medije rasprostiru

Bacc. ing. sec., Baldini 5A, Vrvari, 52440 Poreč, Hrvatska.E-mail: mmasatov@veleri.hr

2 Dipl. ing., Služba za akustička mjerenja pri Zavodu za javno zdravstvo Istarske županije, Nazorova 23, HR-2100 52000 Pula; E-mail: akustika@zzjziz.hr

3 Dr. sc., dipl. ing. strojarstva, predavač, Veleučilište u Rijeci, Vukovarska 58, 51000 Rijeka, Hrvatska. E-mail:mkrsulja@veleri.hr.

4 Datum primitka rada: 15. 1. 2017.; datum prihvaćanja rada: 15. 2. 2017. 
longitudinalno, a kroz krute i tekuće medije transverzalno. Pri longitudinalnom rasprostiranju čestice titraju u smjeru širenja vala, dok kod transverzalnog gibanja čestice titraju okomito na smjer širenja vala.

Prema tome, razlikujemo tri uzroka nastanka buke (Jelaković 1978:219):

- zračna buka, koja nastaje u prostoriji u kojoj smeta (longitudinalni valovi nastali širenjem zvučnih tlakova kroz zrak, npr. govor ili glazba);

- zračna buka, koja se prenosi izvana ili iz druge prostorije u prostoriju u kojoj smeta;

- $\quad$ vibracijska (strukturna) buka, koja se u prostoriju u kojoj smeta prenosi preko građevinskih konstrukcija, tj. širenjem zvučnih valova (longitudinalno i transverzalno) kroz čvrste materijale, građevinske elemente.

Udarni zvučni valovi koji se koriste za određivanje udarne zvučne izolacije u ovome istraživanju spadaju pod vibracijsku (strukturnu) buku.

Kada zvuk titra u zraku i prenosi se na određenu udaljenost ovisno o razini zvučnog intenziteta te razini zvučne snage stvara se slobodno zvučno polje. To vrijedi između prometnice i zgrade gdje se buka širi približno kao slobodno zvučno polje, međutim kod nailaska na prepreku dolazi do refleksije a kod prostorija u zgradi nastaju višestruke refleksije. Prema tome, sama sloboda zvučnog polja (Q) ovisi o faktoru usmjerenosti izvora koji može biti u zraku slobodan, na tlu (1 ravnina) omeđen s 2 ravnine ili u kutu omeđenom s tri ravnine. Razina buke u slobodnom zvučnom polju $\left(L_{p(r)}\right)$ ovisi o udaljenosti izvora $(r)$ do točke u kojoj se razina zvučnog tlaka mjeri (2) (Sever, 2007:51).

$$
L_{p(r)}=L_{w}+10 \log Q-20 \log r-11[\mathrm{~dB}]
$$

Kada naiđe na prepreku zvuk se prenosi njome, tako da, ovisno o mediju prepreke, pri prolazu dolazi do određenog smanjenja razine zvučnog tlaka (prigušenja, srednja vrijednost indeksa zvučne izolacije $R_{w}(3)$ ). Kod srednje razine zvučne izolacije promatra se promjena razine zvučnog tlaka u predajnoj $\left(L_{1}\right)$ i prijamnoj prostoriji $\left(L_{2}\right)$ te vrijeme odjeka koje ovisi o površini pregradnog zida $(S)$ i apsorpcijske površine $\left(A_{r}\right)$.

$$
R_{W}=L_{1}-L_{2}+10 \log \frac{S}{A_{r}} \mathrm{~dB}
$$

Dakle, određena energija vala dijelom prolazi kroz zid dijelom ostaje u zidu i dijelom se reflektira u npr. zid i izlazi iz zida natrag u zrak (slika 1). Osim toga, prenosi se i preko ventilacije, poda, stropa i bočnih zidova. Svakako treba uzeti u obzir i smanjenje buke zbog udaljenosti od prepreke. U ovome radu ispituje se upravo to, neželjeni zvukovi koji ulaze ili izlaze iz stambenih ili poslovnih prostora. Neželjeni zvukovi u ovome istraživanju uzrokovani su najviše prometnicom koja se nalazi do novoizrađene zgrade koju se ispituje. No pad predmeta, udarac čekića, izvođenje radova pomoću raznih pila i bušilica proizvodi visoke razine zvučnog tlaka koje se šire duž zgrade. Stoga je i važna zvučna izolacija pregradnim zidovima i dodatnim medijima koji mogu pomoći da se smanji razina buke koja se prenosi (npr. kamena vuna, staklena vuna, različite spužve i slično). 
Slika 1. Prijenos zvuka iz prostorije u prostoriju

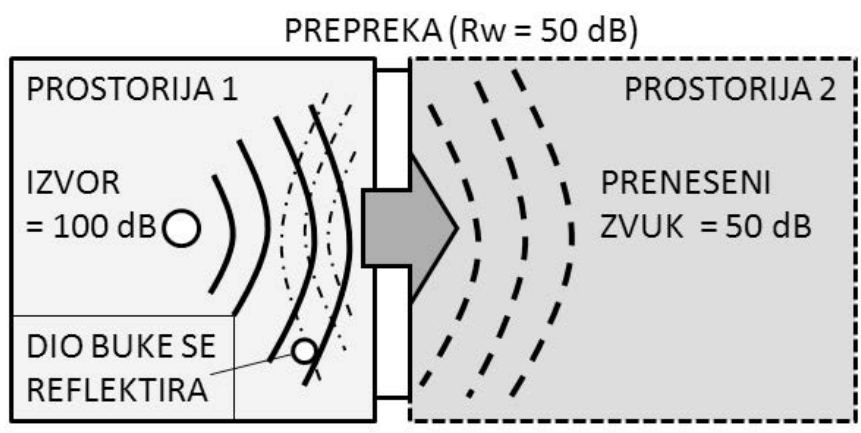

Izvor: obrada autora

Prema tome, moguće je okvirno predvidjeti srednje zvučno prigušenje pomoću izraza (4) (Jelaković,1978:230):

$$
R=14+14 \log _{10}(m)
$$

gdje $m$ ima značenje plošne mase $(m=r \cdot d)$, gdje je $r$ gustoća $\left(\mathrm{kg} / \mathrm{m}^{3}\right)$ a debljina $(\mathrm{m})$ pregrade. Kao primjer iz izraza (4) izračunato je prosječno smanjenje zvuka kod nekoliko građevinskih materijala, a dobiveni rezultati prikazani su u tablici 1.

Tablica 1. Prikaz materijala, njihove gustoće i srednjeg prigušenja

\begin{tabular}{|c|c|c|c|}
\hline Materijal & Gustoća $\left(\mathrm{kg} / \mathrm{m}^{3}\right)$ & $\begin{array}{c}\text { R, srednje zvučno } \\
\text { prigušivanje }(\mathrm{dB}), \\
\mathrm{d}=0,1 \mathrm{~m}\end{array}$ & $\begin{array}{c}\text { R, srednje zvučno } \\
\text { prigušivanje }(\mathrm{dB}), \\
\mathrm{d}=0,2 \mathrm{~m}\end{array}$ \\
\hline Šperploča & 580 & 38,69 & 42,90 \\
\hline Vlaknasta ploča & 810 & 40,72 & 44,93 \\
\hline Aluminij & 2.700 & 48,04 & 52,25 \\
\hline Suha žbuka & 750 & 40,25 & 44,47 \\
\hline Staklo & 2.500 & 47,57 & 51,79 \\
\hline Beton & 2.300 & 47,06 & 51,28 \\
\hline Cigla & 1.900 & 45,90 & 50,12 \\
\hline Željezo & 8.100 & 54,72 & 58,93 \\
\hline Olovo & 11.200 & 56,69 & 60,90 \\
\hline
\end{tabular}

Izvor: Modificirano prema Jelaković (1978) i http://personal.cityu.edu.hk/ bsapplec/sound4.htm

\section{OSJET ZVUKA I DOPUŠTENE RAZINE BUKE}

Osjet zvuka ovisi o intenzitetu zvuka, frekvenciji, vremenu izloženosti te osobnoj osjetljivosti čovjeka. Ovisno o čovjekovom okruženju različite su i razine izloženosti buci, tako je npr. uobičajena 
buka u uredu $50 \mathrm{~dB}$, prometna buka oko $80 \mathrm{~dB}$, a buka u diskotekama doseže čak visokih $110 \mathrm{~dB}$. Prema tome izdana je opća klasifikacija razina buke s obzirom na djelovanje na čovjeka (Radanović, 1999:19):

- Do $60 \mathrm{~dB}(\mathrm{~A})$ - područje samo psihološkog djelovanja.

- Od 60 do $90 \mathrm{~dB}(\mathrm{~A})$ - područje ozbiljnih psiholoških kao i neurovegetativnih smetnji.

- $\quad \operatorname{znad} 90 \mathrm{~dB}(\mathrm{~A})$ - područje oštećenja sluha.

- $\operatorname{lznad} 120 \mathrm{~dB}(\mathrm{~A})$ - područje akutnog oštećenja sluha.

Buka na čovjeka može djelovati auralno i ekstraauralno. Auralno djelovanje je na sam organ sluha, a ekstrauralno je djelovanje na cijeli čovjekov organizam. Svakako čovjek čuje pomoću organa uha koje se sastoji od vanjskog, srednjeg i unutarnjeg uha. No ono što se neprimjetno oštećuje je unutarnje uho u kojemu je smješten Cortijev organ koji omogućava da se zamjećuju frekvencije od 16 do $16000 \mathrm{~Hz}$ slanjem električnih impulsa u mozak. Sam Cortijev organ sastoji se od niza dlačica, tj. cilijarnih stanica koje omogućuju da se pojedine frekvencije primjećuju. Nažalost gubitak cilijarnih stanica događa se postepeno pri izloženosti višim razinama zvučnoga tlaka (> 75 $\mathrm{dB}$ prema Svjetskoj zdravstvenoj organizaciji), a nakon gubitka se ne regeneriraju.

Ovisno o vremenu izlaganja buci propisana je prema ISO 1999:1990, točka 3.6. Propisana dnevna razina izloženosti buci $\left(L_{E X X}\right)(d B(A)$ re. $20 \mu \mathrm{Pa})$.

Za istraživanje nam je potreban Pravilnik o najvišim dopuštenim razinama buke u sredini u kojoj ljudi rade i borave te on propisuje sljedeće razine (Zakon o zaštiti od buke (NN 30/09)):

- donja upozoravajuća granica, $L_{E x, 8 h}=80 \mathrm{~dB}(\mathrm{~A})$.

- gornja upozoravajuća granica, $L_{E x, s h}=85 \mathrm{~dB}(\mathrm{~A})$

- granična vrijednost izloženosti, $L_{E x, s h}=87 \mathrm{~dB}(\mathrm{~A})$.

- Posljedice izlaganja razinama zvučnih tlakovima iznad $85 \mathrm{~dB}$ u 8 radnih sati mogu biti sljedeće smetnje:

- Tinitus (subjektivni tinitus - šum u uhu koji predstavlja osjet zvuka bez zvučnog podražaja, postoji i objektivni tinitus koji može biti uzrokovan bolestima krvožilnog sustava).

- Poremećaj sna (uzrokovan povišenim pragom čujnosti koji traje i nakon prestanaka zvučnog podražaja).

- Narušena koncentracija (povišeni krvni tlak).

- Nervoza (nesposobnosti u komunikaciji i grešaka pri radu zbog krivog prenošenje informacija).

Pri gornjoj i graničnoj vrijednosti izloženosti obavezno je korištenje OZO's, (Horvat, Regent, 2009:98). Isti pravilnik propisuje najviše dopuštene ocjenske razine u otvorenom prostoru. $\mathrm{Za}$ naš primjer bitna je točka 3 . iz tablice 2 , koja propisuje $L_{\text {Raeq }}=55 \mathrm{~dB}$ za dan i $L_{\text {Raeq }=} 45 \mathrm{~dB}$ za noć za zonu mješovite, pretežito stambene namjene.

Akronim za „osobnu zaštitnu opremu“. 
Tablica 2. Najviše dopuštene razine u otvorenom prostoru

\begin{tabular}{|c|c|c|c|}
\hline \multirow{2}{*}{$\begin{array}{l}\text { Zona } \\
\text { buke }\end{array}$} & \multirow{2}{*}{ Namjena prostora } & \multicolumn{2}{|c|}{$\begin{array}{l}\text { Najviše dopuštene ocjenske razine buke } \\
\text { imisije } L_{\text {RAeq }} \mathrm{u} \mathrm{dB}(\mathrm{A})\end{array}$} \\
\hline & & za dan $\left(L_{\text {day }}\right)$ & Noć $\left(L_{\text {night }}\right)$ \\
\hline 1. & $\begin{array}{l}\text { Zona namijenjena odmoru, } \\
\text { oporavku i liječenju }\end{array}$ & 50 & 40 \\
\hline 2. & $\begin{array}{l}\text { Zona namijenjena samo } \\
\text { stanovanju i boravku }\end{array}$ & 55 & 40 \\
\hline 3. & $\begin{array}{l}\text { Zona mješovite, pretežito } \\
\text { stambene namjene }\end{array}$ & 55 & 45 \\
\hline 4. & $\begin{array}{c}\text { Zona mješovite, pretežito poslovne } \\
\text { namjene sa stanovanjem }\end{array}$ & 65 & 50 \\
\hline 5. & $\begin{array}{l}\text { Zona gospodarske namjene } \\
\text { (proizvodnja, industrija, } \\
\text { skladišta, servisi) }\end{array}$ & \multicolumn{2}{|c|}{$\begin{array}{l}\text { - Na granici građevne čestice unutar zone buka ne } \\
\text { smije prelaziti } 80 \mathrm{~dB}(\mathrm{~A}) \\
\text { - Na granici ove zone buka ne smije prelaziti } \\
\text { dopuštene razine zone s kojom graniči }\end{array}$} \\
\hline
\end{tabular}

Izvor: Pravilnik o najvišim dopuštenim razinama buke u sredini u kojoj ljudi rade i borave (NN br. 145/04)

Buka znatno djeluje na koncentraciju; ovisno o vrsti posla potrebna je veća ili manja koncentracija. Za stambene i poslovne prostore bitan je rad koji zahtijeva često komuniciranje govorom koji propisuje $L_{A, e q}=50 \mathrm{~dB}$.

\section{ZAŠTITA OD BUKE}

Zaštita od buke dijeli se na aktivne i pasivne mjere zaštite. Aktivnim mjerama smatraju se sve one mjere već poduzete u samom projektiranju i izgradnji zgrade, a pasivne mjere su osobna zaštitna oprema, kao što su čepići za uši, štitnici za uši, semiauralni štitnici i slično.

Tema ovog rada bazira se na zvučnoj izolaciji. To je svojstvo građevinske konstrukcije da onemogući prijenos zvučne energije izjedne prostorije u drugu. Dakle, građevina bi trebala biti tako konstruirana da sa svojom konstrukcijom i sa svom tehnologijom u sebi smanjuje prijenos buke te omogućuje nesmetani čovjekov rad i svakodnevnicu. Dobra zvučna izolacija postavlja se već od temelja, stropa i susjednih zidova. Za međukatne konstrukcije najčešće se koristi plivajući pod ${ }^{6}$, za zidove kamena vuna ${ }^{7}$. Što su materijali teži to oni teže provode zvuk, zato su beton i cigla odlični izolatori. Također se preporučuju dvostruko, čak i trostruko ostakljeni prozori, te teška i masivna vrata kako bi cijeli sustav dobro brtvio i zvuk ne bi „curio” izvana unutra.

6 Služe za izolaciju međukatnih konstrukcija u zgradama. Sastoje se od gornje ploče koja slobodno „pliva” na elastičnom sloju od kamene vune, elastificiranog stiropora, pluta i sl. (Radanović, 1999:43).

7 Može smanjiti prijenos buke za više od $50 \mathrm{~dB}$. 
Osim zvučne izolacije također postoje apsorberi koji se mogu postavljati na podove i stropove kako bi smanjili razinu reflektiranog zvuka. Kada zvuk naiđe na prepreku dio energije se reflektira, prijeđe kroz prepreku ili pretvori u toplinu. Refleksija zvuka postoji najčešće $u$ velikim praznim prostorima, halama. Zvuk se u tim slučajevima konstantno odbija o zidove, strop i pod. Postoje porozni, membranski i rezonantni apsorberi kojima je to moguće smanjiti. Porozni su uglavnom spužvasti te se zvuk gubi u njihovoj teksturi. Membranski su uglavnom čvrste ploče, a rezonantni su šupljikave ploče te provode zrak kroz rupice.

\section{ISPITIVANJE ZVUČNE IZOLACIJE NA NOVOIZGRAĐENOJ ZGRADI}

$\mathrm{U}$ radu će se provesti ispitivanje zračne zvučne i udarne buke u stambeno-poslovnoj građevini, u ulici M. Belušića na lokaciji k. č. 2259/3 k. o., Pazin (slika 2). Ispitivana građevina sastoji se od prizemlja u kojemu će biti smješteni poslovni prostori uredskog tipa, buka maksimalno do $50 \mathrm{~dB}$, te tri kata stambenih prostora. Građevina se nalazi uz glavnu prometnicu pored benzinske pumpe, nasuprot autobusnog kolodvora. Prometna buka u najvišim točkama jedva doseže $70 \mathrm{~dB}$. Pri istraživanju koristile su se dvije metode. Primarna metoda istraživanja je ispitivanje zračne zvučne izolacije, a sekundarna je ispitivanje udarne zvučne izolacije.

Slika 2. Stambeno-poslovna novoizgrađena zgrada u Pazinu

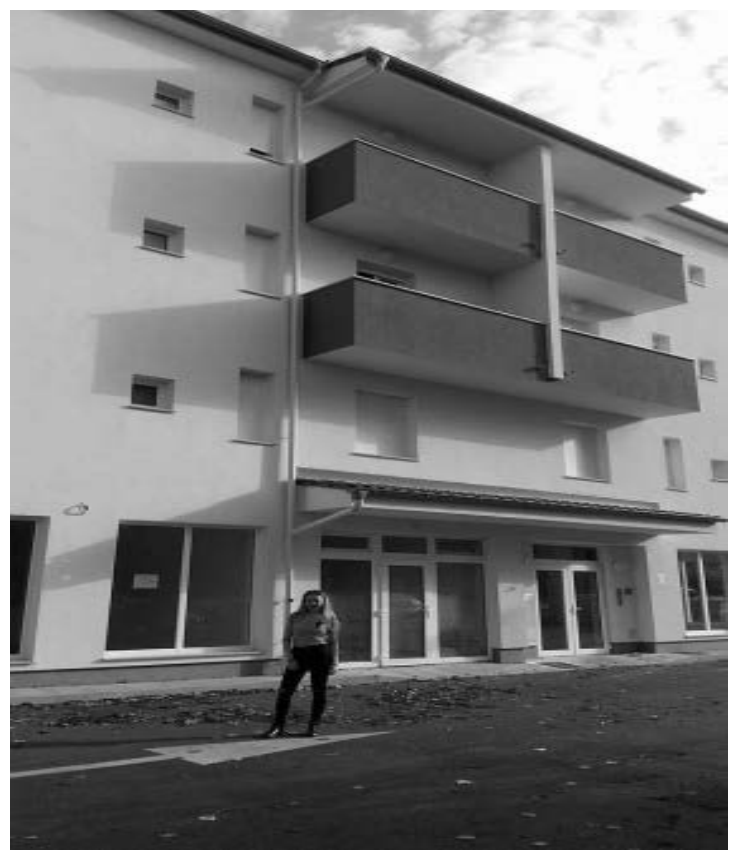

Izvor: obrada autora

Ispitivanjeje provedeno sciljem zaštite na radu te radi tehničkog pregleda ispravnosti novoizgrađene zgrade. Mjerenja trebaju zadovoljiti zahtjeve norme HRN U.J6.201. 
One su prikazane u tablici 3.

Tablica 3. Zahtjevi norme HRN U.J6.201.

\begin{tabular}{|clcc|}
\hline Redni broj & \multicolumn{1}{c}{\begin{tabular}{c}
\multicolumn{1}{c}{ Funkcija pregrada } \\
A-Stambene i stambeno-poslovne zgrade
\end{tabular}} & $\begin{array}{c}R_{\text {wmin }} \\
\mathrm{dB}\end{array}$ & $\begin{array}{c}L_{\text {wmax }} \\
\mathrm{dB}\end{array}$ \\
\hline A.1 & Zid između dva stana & 52 & - \\
\hline A.2 & $\begin{array}{l}\text { Zid (zidovi) s vratima između boravišnih prostorija stana i } \\
\text { zajedničkog stepeništa }\end{array}$ & \multicolumn{2}{c|}{$D_{\text {wmmin }} \mathrm{dB}$} \\
\hline A.8 & $\begin{array}{l}\text { Međukatna konstrukcija između bilo kojih prostorija dva } \\
\text { stana }\end{array}$ & 52 & 68 \\
\hline A.9 & $\begin{array}{l}\text { Međukatna konstrukcija ispod stana prema prostorijama } \\
\text { druge namjene ( poslovnim prostorijama, } \\
\text { prodavaonicama,...) }\end{array}$ & 57 & 68 \\
\hline
\end{tabular}

Izvor: ZZJZIŽ, RN-ZZI-UZI-19/15, Izvještaj o ispitivanju zračne i udarne zvučne izolacije

Prvi način mjerenja vrši se tako da se izvor zvuka postavlja u predajnu prostoriju, generira se šum na pojačalu te se zvukomjerom mjeri razina buke u tom prostoru. Nakon toga izvor zvuka ostaje $\mathrm{u}$ istoj prostoriji (predajnoj), no zvuk se mjeri u drugoj (prijamnoj) prostoriji. Kada su izvršena oba mjerenja, mjeri se još vrijeme odjeka u prijamnoj prostoriji kao i razina pozadinske buke te geometrija navedenih prostorija i ispitne pregrade. Što je veća razlika razina to je bolja izolacija. Naravno, razina u prijamnoj prostoriji puno je manja od predajne.

Drugi način mjerenja izolacije vrši se pomoću toptalice. Ona se postavlja u predajnu prostoriju, te se ovoga puta zvuk mjeri samo u prijamnoj sobi. Rezultat mjerenja pokazuje nam kolika je zvučna izolacija, primjerice, međukatne konstrukcije (pod ili strop) prostorije.

Osnovni mjerni instrument pomoću kojeg se provodilo ispitivanje zvučne izolacije je prijenosni modularni programibilni analizator zvuka tip 2250 proizvođača Brüel \& Kjaer s pripadajućim baznim softverima; softver omogućuje mjerenje, pohranjivanje te analizu podataka; slika 3.

Slika 3. Zvukomjer Brüel \& Kjaer 2250

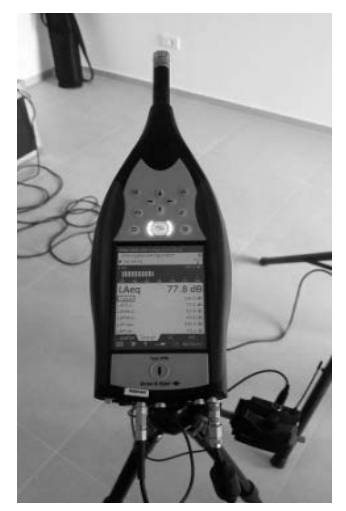

Izvor: obrada autora 
Izvor zvuka je uređaj za generiranje izvora zvuka, slika 4. Koristi se u kombinaciji sa zvukomjerom i sastoji se od 12 zvučnika koji su tako postavljeni da šire zvuk u svim smjerovima jednako.

Slika 4. Uređaj za generiranje izvora zvuka

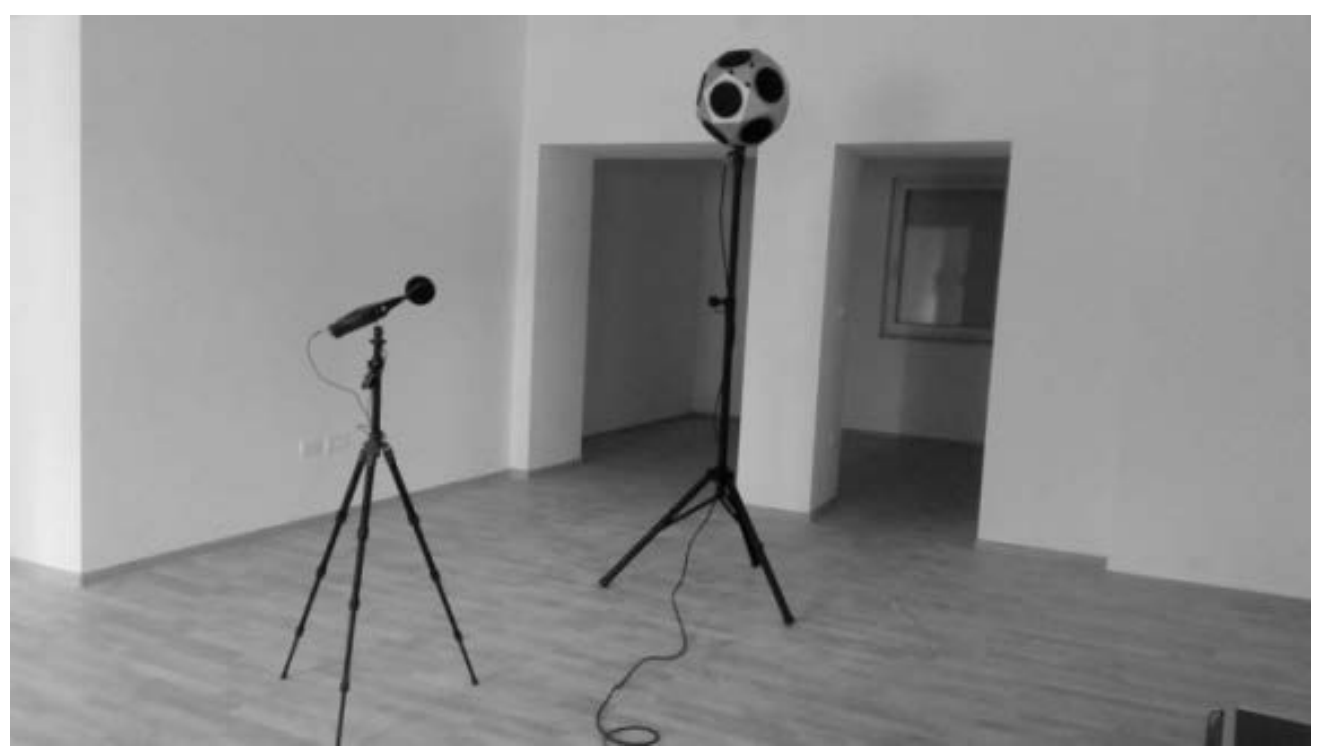

Izvor: obrada autora

Za ispitivanje udarne zvučne izolacije koristila se toptalica u kombinaciji sa zvukomjerom. Toptalica je uređaj koji proizvodi udarni zvuk, slika 5 . Uređaj je robustan ali prijenosan i ima daljinski upravljač. Izvor udarnog zvuka sastoji se od pet metalnih čekića mase $0,5 \mathrm{~kg}$ koji slobodnim padom s visine 4 $\mathrm{cm}$ proizvode točno 10 udaraca u jednoj sekundi.

Slika 5. Toptalica

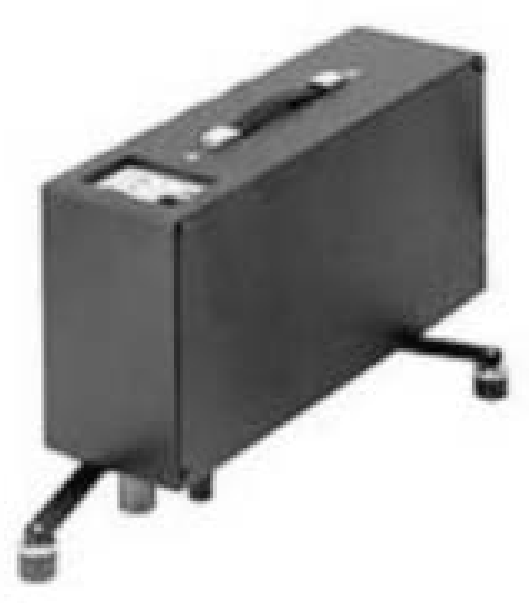




\section{1 Ispitivanje zračne zvučne izolacije}

Frekvencije pri kojima je izvršeno mjerenje prikazane su u tablici 4.

Tablica 4. Frekvencije na kojima je izvršeno mjerenje indeksa zvučne izolacije R'

\begin{tabular}{|c|c|c|c|c|c|c|}
\hline & 100 & 200 & 400 & 800 & 1.600 & 3.150 \\
Frekvencija $\mathrm{f}(\mathrm{Hz})$ & 125 & 250 & 500 & 1.000 & 2.000 & 4.000 \\
& 160 & 315 & 630 & 1.250 & 2.500 & 5.000 \\
\hline & 49,5 & 42,8 & 46,7 & 49,3 & 54,0 & \\
$\mathrm{R}^{\prime} 1 / 3$ oktave dB & 39,5 & 44,7 & 47,8 & 52,4 & 55,4 & 61,3 \\
& 43,1 & 44,9 & 49,2 & 53,7 & 57,8 & \\
\hline
\end{tabular}

Izvor: obrada autora

Zračna zvučna izolacije ispitana je na zidu između stana $H$ (soba br. 2) na 2. katu i stana I (soba br. 3) na 2. katu. Tlocrt je prikazan na slici 6 , strjelicama je označeno mjesto mjerenja zvučne izolacije. Volumen prostorije u kojoj se nalazi zvukomjer iznosi $86 \mathrm{~m}^{3}$, a prostorije u kojoj se nalazi zvučnik ili izvor zvuka 93,60 m³. Ispitivani pregradni zid koji odvaja dvije prostorije ima površinu od $14 \mathrm{~m}^{2}$.

Slika 6. Tlocrt 2. kata

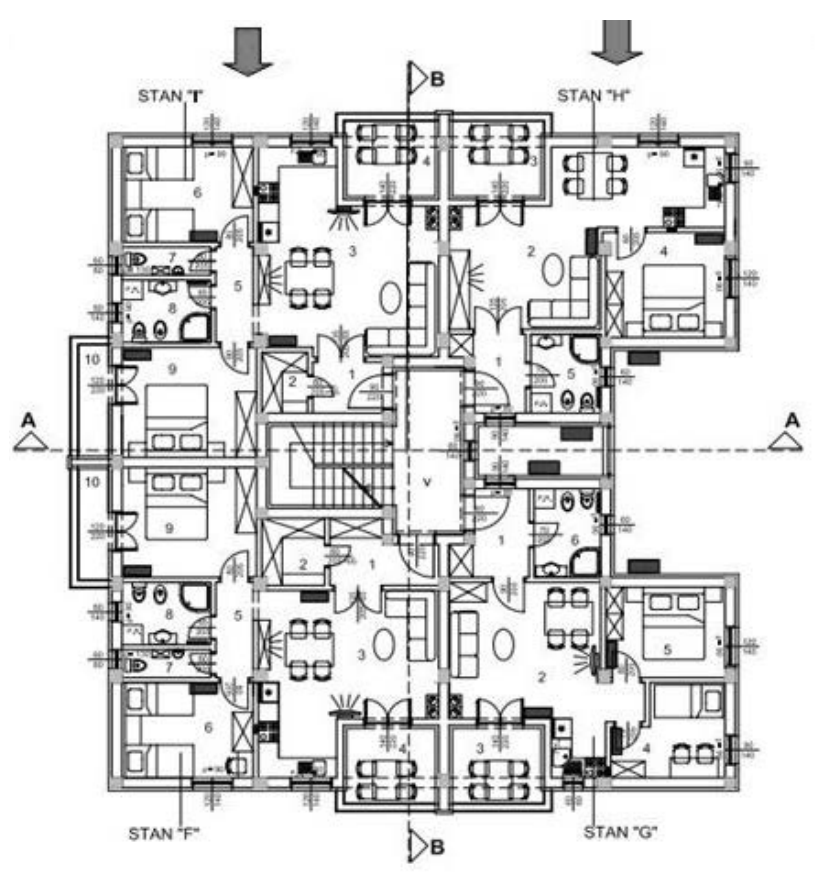

Izvor: http://www.usluga-pazin.hr/wp-content/uploads/2013/12/Katalog_stanova.pdf

Na slici 7 prikazani su rezultati mjerenja, indeks zvučne izolacije $R^{\prime} \mathrm{dB}$ u normiranom referentnom tercnom području od $100 \mathrm{~Hz}$ do $3150 \mathrm{~Hz}$. 


\section{Masatović, E. Ciliga, M. Kršulja: Ispitivanje zvučne izolacije u novoizgrađenoj zgradi Zbornik Veleučilišta u Rijeci, Vol. 5 (2017), No. 1, pp. 159-174}

Rezultat se dobiva određivanjem jednobrojne vrijednosti zvučne izolacije. Nju određujemo pomoću normirane referentne krivulje, slika 7 desno. Referentna krivulja dijeli područje zvučne izolacije na dva dijela - povoljno i nepovoljno područje. Nepovoljno područje za zračnu zvučnu izolaciju je ispod referentne krivulje. Referentna krivulja vrijedi za odredivanje jednobrojnog indeksa zvučne izolacije $R_{w}\left(R_{w}^{\prime}\right)$ pregrada (prvi je mjeren u laboratoriju, a drugi u zgradi).

Osnovno načelo određivanja jednobrojne vrijednosti zvučne izolacije jest da se referentna krivulja vertikalno u određenim koracima pomiče prema izmjerenim tercnim vrijednostima, dok se ne zadovolji uvjet da srednje nepovoljno odstupanje od pomaknute referentne krivulje bude jednako ili upravo manje od $2 \mathrm{~dB}$. Srednje nepovoljno odstupanje je zbroj svih nepovoljnih odstupanja podijeljen s ukupnim brojem terci (za osnovno frekvencijsko područje taj broj je 16). Jednobrojna vrijednost zvučne izolacije jest vrijednost pomaknute referentne krivulje očitana na frekvenciji 500 $\mathrm{Hz}$ (Radanović, 1999:53).

Slika 7. Rezultati mjerenja 1 lijevo i desno referentna krivulja prema ISO 717-1 (izvor HRN EN ISO717-1)
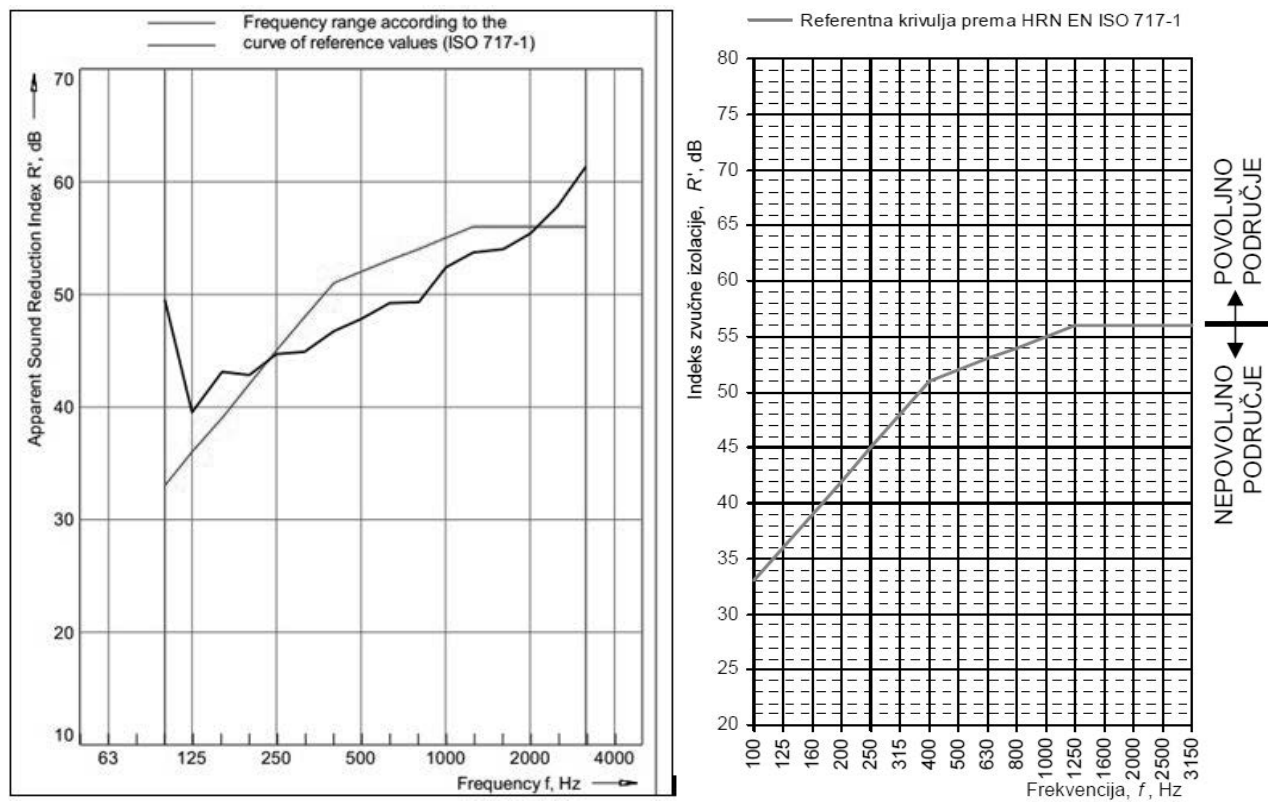

Izvor: obrada autora

Prema tome, možemo reći da je rezultat našeg mjerenja $52 \mathrm{~dB}$. Iz građevinskog projekta u dijelu projekta zaštite od buke navode se kriteriji za ocjenu izvedene pregradne konstrukcije: RZ1razdjelni zidovi između grijanog prostora, stanovi sa zvučnom izolacijom $R_{w \min }=52 \mathrm{~dB}$. Dakle, naša građevina zadovoljava akustične zahtjeve. 


\section{2 Ispitivanje udarne zvučne izolacije}

Ispitivanje udarne izolacije provodilo se na horizontalnoj pregradnoj konstrukciji između stana $E$ (soba br. 3) na 1. katu i poslovnog prostora u prizemlju građevine. Presjek zgrade prikazan je na slici 9; strelicama su naznačena mjesta mjerenja udarne izolacije.

Volumen prostorije u kojoj se nalazi zvukomjer iznosi $167,5 \mathrm{~m}^{3}$. Ispitivana međukatna konstrukcija koja odvaja dvije prostorije ima površinu od $57,8 \mathrm{~m}^{2}$.

Slika 9. Presjek zgrade

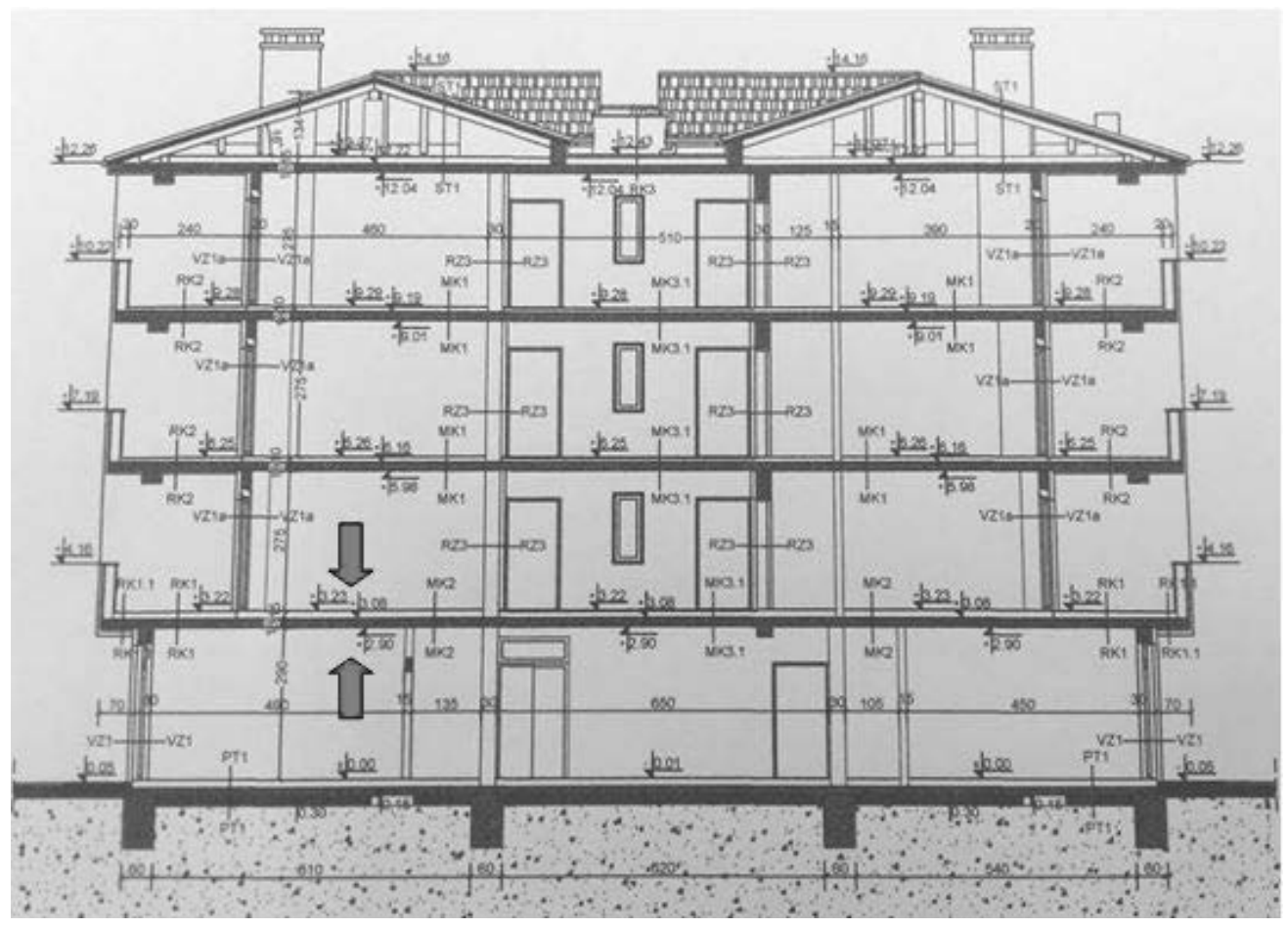

Izvor: http://www.usluga-pazin.hr/wp-content/uploads/2013/12/Katalog_stanova.pdf

Frekvencije pri kojima je izvršeno mjerenje tablično su prikazane u tablici 5.

Tablica 5. Normalizirane razine udarnog zvuka L'n pri mjerenim frekvencijama

\begin{tabular}{|c|c|c|c|c|c|c|}
\hline & 100 & 200 & 400 & 800 & 1.600 & 3.150 \\
Frekvencija $\mathrm{f}(\mathrm{Hz})$ & 125 & 250 & 500 & 1.000 & 2.000 & 4.000 \\
& 160 & 315 & 630 & 1.250 & 2.500 & 5.000 \\
\hline & 60,7 & 51,2 & 40,1 & 41,3 & 28,1 & \\
Ln' 1/3 oktave dB & 56,9 & 44,6 & 39,6 & 37,6 & 24,1 & $22,7 \mathrm{~B}$ \\
& 52,3 & 41,7 & 39,8 & 32,0 & $21,8 \mathrm{~B}$ & \\
\hline
\end{tabular}

Izvor: obrada autora 


\section{Masatović, E. Ciliga, M. Kršulja: Ispitivanje zvučne izolacije u novoizgrađenoj zgradi Zbornik Veleučilišta u Rijeci, Vol. 5 (2017), No. 1, pp. 159-174}

Na slici 10 lijevo prikazani su rezultati mjerenja, Normalizirana razina udarnog zvuka L'n dB u normiranom referentnom tercnom području od $100 \mathrm{~Hz}$ do $3150 \mathrm{~Hz}$.

Rezultat se dobiva određivanjem jednobrojne vrijednosti udarne zvučne izolacije. Nju dobivamo pomoću vrednovane normalizirane razine udarnoga zvuka $L n, w$ (L'n,w) i pripadajuće normirane referentne krivulje, slika 10 desno. Svaka referentna krivulja dijeli područje zvučne izolacije na dva dijela - povoljno i nepovoljno područje. Nepovoljno područje za udarnu zvučnu izolaciju je iznad referentne krivulje, a povoljno ispod nje. Osnovno načelo određivanja jednobrojne vrijednosti udarne zvučne izolacije jest da se referentna krivulja vertikalno u koracima od po 1 $\mathrm{dB}$ po cjelobrojnim iznosima na skali pomiče prema izmjerenim tercnim vrijednostima, dok se ne zadovolji uvjet da srednje nepovoljno odstupanje od pomaknute referentne krivulje bude jednako ili upravo manje od $2 \mathrm{~dB}$. Srednje nepovoljno odstupanje zbroj je svih nepovoljnih odstupanja podijeljen s ukupnim brojem terci (za osnovno frekvencijsko područje taj broj je 16). Jednobrojna vrijednost zvučne izolacije jest vrijednost pomaknute referentne krivulje očitana na frekvenciji 500 $\mathrm{Hz}$.

Slika 10. Rezultati mjerenja 2 lijevo i desno referentna krivulja prema ISO 717-2

(izvor HRN EN ISO 717-2)
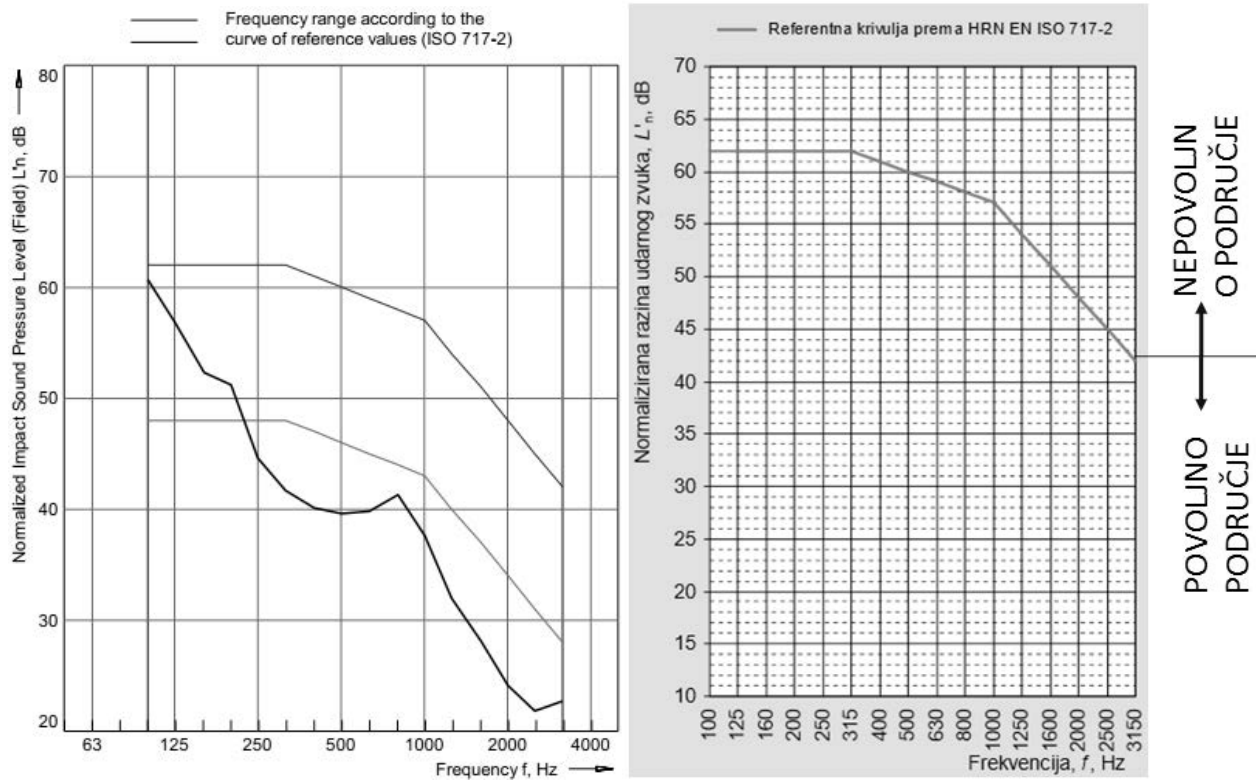

Izvor: obrada autora

Prema tome, možemo zaključiti da je rezultat našeg mjerenja $46 \mathrm{~dB}$, što zadovoljava akustične zahtjeve prema važećoj normi HRN U. J 6.201 - Akustika u zgradarstvu - Tehnički uvjeti za projektiranje i građenje zgrada: Međukatna konstrukcija ispod stana prema prostorijama druge namjene (poslovnim prostorijama, prodavaonicama...) propisuje $L_{\text {wmax }}=68 \mathrm{~dB}$. 


\section{REZULTATI I RASPRAVA}

Rezultati su prikazani u dva dijela za zračnu zvučnu izolaciju i udarnu zvučnu izolaciju.

\section{1 Zračna zvučna izolacija}

Ispitivanje koje je provedeno na zidu između stana I i stana $\mathrm{H}$ prikazalo se zadovoljavajućim zato što je rezultat našeg mjerenja $52 \mathrm{~dB}$. Rezultat se dobiva pomoću normirane referentne krivulje za zračnu izolaciju i očitava se kao jednobrojna vrijednost.

Zahtjevi norme HRN U.J6.201. govore da zid između dva stana mora imati $R_{\text {wmin }}=52 \mathrm{~dB}$. Dakle, naš ispitani zid u granici je dopuštenog, odnosno $R_{\text {wmin }}$ te tako zadovoljava sve akustičke i tehničke zahtjeve. Da je naš rezultat mjerenja, odnosno jednobrojna vrijednost kojim slučajem $<52 \mathrm{~dB}$, zvučna izolacija ne bi zadovoljila te bi se zahtijevala detaljna analiza "curenja“ zraka. Sve što je > 52 dB zadovoljava.

\subsection{Udarna zvučna izolacija}

Ispitivanje koje je provedeno na međukatnoj konstrukciji između trećeg stana prvog kata i poslovnog prostora ispod njega također zadovoljava sve akustičke i tehničke zahtjeve. Naš rezultat se očitava kao jednobrojna vrijednost pomoću normirane referentne krivulje za udarnu izolaciju $\mathrm{i}$ on je $46 \mathrm{~dB}$ u ovom slučaju.

Zahtjevi norme HRN U.J6.201. govore da međukatna konstrukcija ispod stana prema prostorijama druge namjene ( poslovnim prostorijama, prodavaonicama...) propisuje $L_{\text {wmax }}=68 \mathrm{~dB}$. U ovom slučaju akustičke i tehničke zahtjeve zadovoljavaju one konstrukcije čija je jednobrojna vrijednost $<68 \mathrm{~dB}$. Da je rezultat našeg mjerenja bio $>68 \mathrm{~dB}$, međukatna konstrukcija ne bi zadovoljavala zahtjeve, te bi bila potrebna detaljna analiza „curenja“ zvuka.

\section{ZAKLJUČAK}

Svijet u kojem živimo je moderan ali i okružen raznim štetnostima koje loše djeluju na čovjekovo zdravlje. Jedna od tih štetnosti je buka. Buka je svaki neželjeni zvuk koji ometa čovjekov rad, psihološko i zdravstveno stanje te njegovo vrijeme odmora. Naime, ona se nažalost zanemaruje. Svrha ovog rada je osvijestiti bitnost zaštite od buke i naglasiti važnost dobre izvedbe zvučne izolacije.

Buka na radu gotovo je neizbježna. Kada je čovjek izložen $8 \mathrm{~h} / \mathrm{d}$ na radnom mjestu, potreban je određeni odmor slušnog organa ali i kompletnog čovjekovog organizma. Odmaramo se u svojim domovima, no to ne bi bilo moguće bez dobro izvedene zvučne izolacije koja smanjuje vanjsku i susjednu buku. Iz navedenog primjera rada može se zaključiti da ispitane tipične pregradne konstrukcije u vidu zaštite na radu zadovoljavaju postavljene akustičke zahtjeve, jer se indeks zvučne izolacije kao i normalizirana razina udarnoga zvuka izračunavaju i ocjenjuju jednobrojnom vrijednošću i zadovoljavaju normu HRN U.J6.201 
$R_{w}=52 \mathrm{~dB}$, što je jednako propisanom $R_{\text {wmin }}=52 \mathrm{~dB}, \mathrm{a} L_{w}=46 \mathrm{~dB}$, što je manje od propisanih $L_{\text {wmax }}$ $=68 \mathrm{~dB}$. Dakle, i zračna i udarna zvučna izolacija zadovoljavaju akustične i tehničke zahtjeve te se novoizgrađena zgrada preporučuje i u poslovne i u stambene svrhe. Novoizgrađena zgrada ne predstavlja nikakve zdravstvene opasnosti za čovjeka i omogućava njegov nesmetani rad i boravak.

Važno je naglasiti da se dobra izolacija odrađuje već u samom projektiranju građevine. Bitno je koji će se materijali koristiti pri izgradnji te gdje će se postavljati izvori zvuka, bučni strojevi, pregrade i slično. Ako je razina buke još uvijek izrazito visoka, moguće je postavljanje apsorbera na stropove i zidove. Oni su uglavnom od spužvastog materijala te se zvuk gubi u njihovoj strukturi i smanjuju njegovu refleksiju. Ako buka još uvijek nije na propisanoj razini, obavezno je korištenje osobne zaštitne opreme te je moguća ugradnja pregrada između radnih mjesta.

\section{LITERATURA}

Horvat, J., Regent, A. (2009) Osobna zaštitna oprema, Veleučilište u Rijeci

http://personal.cityu.edu.hk/ bsapplec/sound4.htm (17. 10. 2016.)

http://personal.cityu.edu.hk/ bsapplec/sound4.htm, (17. 10. 2016.)

http://www.usluga-pazin.hr/wp-content/uploads/2013/12/Katalog_stanova.pdf (25. 11. 2016.)

http://zastitanaradu.com.hr/ (25. 11. 2016.)

Jelaković, T. (1978) Zvuk, sluh, arhitektonska akustika, Školska knjiga, Zagreb, 1978.

Pravilnik o najvišim dopuštenim razinama buke u sredini u kojoj ljudi rade i borave (NN 145/04)

Pravilnik o zaštiti radnika od izloženosti buci na radu (NN 46/08)

Radanović, B. (1999) Fizikalne štetnosti; buka, 2. izdanje, Zagreb: IPROZ

Sever, S. (2007) Fizikalne štetnosti, IPROZ, VŠSR, Zagreb, skripta

Zakon o zaštiti na radu (NN br. 71/14, 118/14 i 154/14).

Zakon o zaštiti od buke (NN 30/09)

www.bksv.com (20. 11. 2016.) 


\title{
INSPECTION OF SOUND ISOLATION ON A NEW BUILDING ${ }^{4}$
}

\begin{abstract}
In this paper field measurement of environmental noise is conducted in working and living environment in the residential and commercial new building in Pazin, street M. Belušic under the Noise Protection Official Gazette No.30 / 09, the regulations on the protection of workers from exposure to noise at work official national gazette $n r .46 / 08$, regulations on maximum permissible noise levels in areas where people work and live, official national gazette nr. 145/04. Noise measurements were performed by sound-level meter SLM Brüel \& Kjaer 2250 and sound or white noise were reproduced by the device for generating sound source Tapping machine ( 5 hammers in line on a camshaft). Sound is measured in the receiver and in the transmitter room to determine the index of sound insulation Rw. After analyzing and processing obtained results a comparison with the current regulations was made. The paper explains the basic concepts related to the description, measurement and determination of acoustic parameters and the effects on humans caused by prolonged exposure to excessive noise levels. In doing so some guidelines for noise protection are mentioned.
\end{abstract}

Key words: noise, sound, personal protective equipment, isolation

Bacc. ing. sec., Baldini 5A, Vrvari, 52440 Poreč, Croatia. E-mail: mmasatov@veleri.hr

M. Eng., Service for Acustic Measurements at Institut for Public Health, Nazorova 23, HR-52000 Pula; E-mail: akustika@zzjziz.hr

PhD, Lecturer, Polytechnic of Rijeka, Vukovarska 58, 51000 Rijeka, Croatia. E-mail: mkrsulja@veleri.hr.

4 Received: 15 January 2017; Accepted: 15 February 2017 
